\title{
Plant RNA Interference in Vitro
}

\author{
C. Matranga AND P.D. Zamore* \\ Department of Biochemistry and Molecular Pharmacology, University of Massachusetts Medical School, \\ Worcester, Massachusetts 01605
}

In the RNA interference (RNAi) pathway, small interfering RNAs (siRNAs) direct the sequence-specific silencing of complementary RNA. RNAi and similar posttranscriptional gene silencing (PTGS) phenomena are found in other eukaryotes, including animals, fungi, protozoa, and plants (Cogoni et al. 1996; Fire et al. 1998; Kennerdell and Carthew 1998; Ngo et al. 1998; Timmons and Fire 1998; Vaucheret et al. 1998; Waterhouse et al. 1998; Lohmann et al. 1999; Sánchez-Alvarado and Newmark 1999; Wianny and Zernicka-Goetz 2000; Caplen et al. 2001; Elbashir et al. 2001c; Volpe et al. 2002; Schramke and Allshire 2003). The RNase III endonuclease, Dicer, initiates RNAi by converting long, doublestranded RNA (dsRNA) into siRNAs (Zamore et al. 2000; Bernstein et al. 2001; Billy et al. 2001), 22-nucleotide guides that direct mRNA cleavage as components of a protein-RNA complex, the RNA-induced silencing complex (RISC) (Hamilton and Baulcombe 1999; Hammond et al. 2000, 2001; Elbashir et al. 2001a). In Drosophila melanogaster, another protein-RNA complex, the RISC loading complex (RLC), assembles one of the two strands of an siRNA into the RISC. The RLC comprises double-stranded siRNA, a heterodimer of the RNase III endonuclease Dicer-2 (Dcr-2) and the siRNAbinding protein R2D2, and other yet identified components (Liu et al. 2003; Pham et al. 2004; Tomari et al. 2004b). Assembly of functional RISC also requires Armitage, a homolog of the Arabidopsis thaliana protein SDE3, a putative helicase required for RNA silencing triggered by sense RNA-expressing transgenes (Dalmay et al. 2001). Armitage is required for oogenesis and RNA interference in vivo (Cook et al. 2004); biochemical evidence suggests that Armitage acts in RISC assembly after the RLC (Tomari et al. 2004b).

Argonaute family proteins form the catalytic core of the RISC (Hammond et al. 2001; Caudy et al. 2002; Hutvágner and Zamore 2002; Martinez et al. 2002; Mourelatos et al. 2002; Tabara et al. 2002; Hutvágner et al. 2004; Liu et al. 2004; Martinez and Tuschl 2004; Meister et al. 2004; Parker et al. 2004; Rand et al. 2004; Song et al. 2004) and are thus required genetically for RNAi (Tabara et al. 1999; Fagard et al. 2000; Grishok et al. 2000; Catalanotto et al. 2002; Caudy et al. 2002; Morel et al. 2002; Pal-Bhadra et al. 2002; Williams and Rubin 2002; Doi et al. 2003). Transfer of the siRNA guide strand, the strand complementary to the target RNA, from the RLC to the RISC requires Argonaute 2, consistent with its proposed role as an acceptor of unwound siRNA guide strand (Okamura et al. 2004; Tomari et al. 2004a).

Extracts from Drosophila and mammalian cells are important tools for dissecting the mechanism of RNAi in vitro, yet no comparable in vitro system is available for plant RNAi initiated by siRNAs. In plants, wheat germ extract is an important tool for studying RNA silencing, but wheat germ extracts cannot be programmed with synthetic duplex siRNAs. Wheat extracts recapitulate some RNA silencing activities, including RNA-dependent RNA polymerase activity and small RNA production from long dsRNA ("dicing") (Tang et al. 2003). Wheat germ extract also contains functional RISCs programmed with microRNAs (miRNAs), small, endogenous RNA guides that control the expression of messenger RNA (mRNA) targets, typically by cleaving them, suggesting that the extracts are specifically defective in RISC assembly (Tang et al. 2003; Mallory et al. 2004). Exogenous siRNAs trigger target cleavage activity in Drosophila embryo lysates and extracts from cultured mammalian cells (Boutla et al. 2001; Elbashir et al. 2001a,c; Nykänen et al. 2001), but not wheat germ extracts. The siRNAs produced in Drosophila lysate are both double- and single-stranded (Nykänen et al. 2001; Tang et al. 2003), but those produced in wheat germ extract remain double-stranded (Tang et al. 2003), suggesting that synthetic siRNA duplexes do not trigger RNAi in wheat germ extract because they are not unwound.

Here, we demonstrate that wheat germ extract cannot be programmed with exogenous siRNA duplexes because it does not unwind siRNA. In contrast, single-stranded siRNAs directed endonucleolytic cleavage of a corresponding target RNA in wheat germ extract. Wild-type Drosophila embryo and ovary lysate complemented the defect in siRNA unwinding in wheat germ extract. Drosophila ovary lysate defective in RNAi but not siRNA unwinding also rescued wheat germ extract, whereas mutant lysate defective for siRNA unwinding did not. Biochemical complementation of wheat germ RNAi requires both components of the RLC and core components of mature Drosophila RISC.

\section{RESULTS}

\section{Wheat Germ Extract Cannot Unwind siRNA}

Double-stranded siRNAs direct target cleavage in Drosophila embryo lysate (Boutla et al. 2001; Elbashir et 
A

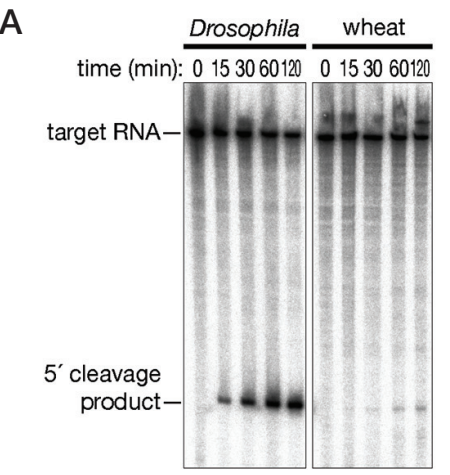

\section{C}

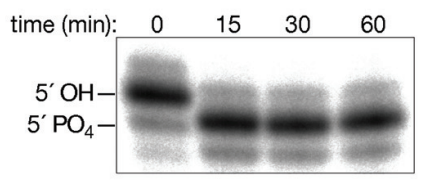

E

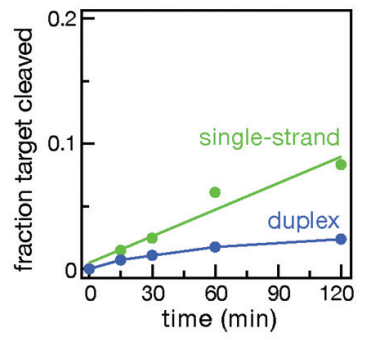

B

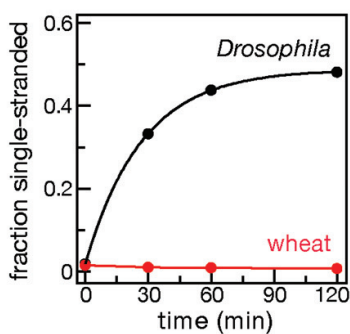

D

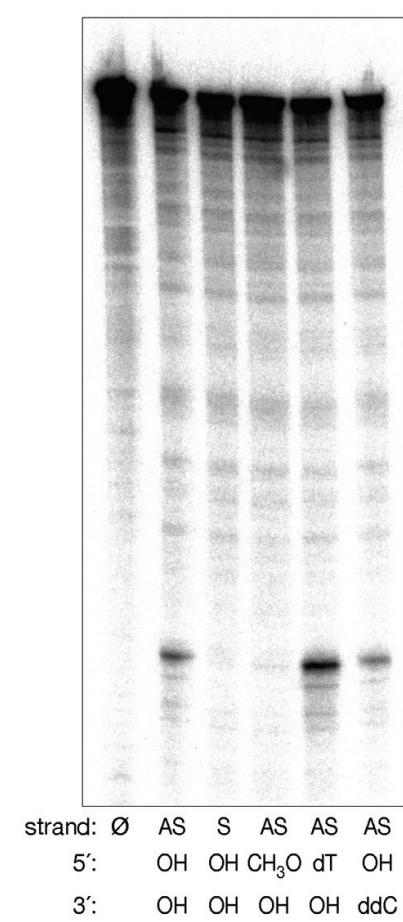

Figure 1. Single-stranded but not doublestranded siRNA triggers RNAi in wheat germ extract. (A) Double-stranded siRNAs direct target cleavage in Drosophila embryo lysate, but triggered only low levels of target cleavage in wheat germ extract. $(B)$ In the presence of ATP, Drosophila embryo lysate (black), but not wheat germ extract (red), unwound an siRNA duplex. (C) A $3{ }^{\prime}-{ }^{32}$ P-radiolabeled siRNA duplex was rapidly phosphorylated upon incubation in wheat germ extract. (D) Single-stranded siRNAs containing $5^{\prime}$ and $3^{\prime}$ hydroxy $(\mathrm{OH})$ termini directed efficient target cleavage in wheat germ extract. The siRNA was rapidly 5' phosphorylated in the wheat germ extract, as shown in $C$. A $5^{\prime}$ methoxy $\left(\mathrm{CH}_{3} \mathrm{O}\right)$ modification, which blocks $5^{\prime}$ phosphorylation, inhibited target cleavage in wheat germ lysate. In order to introduce the $5^{\prime}$ methoxy modification, the first nucleotide of the siRNA was changed from riboU to deoxyT. This change, in the absence of the methoxy modification, did not inhibit target cleavage, as shown by the $5^{\prime}$ dT siRNA. A $2^{\prime}, 3^{\prime}$ dideoxy (ddC) modification of the $3^{\prime}$ end of the siRNA similarly had no significant effect on cleavage. The unmodified sense (S) siRNA triggered no target cleavage and is presented as a negative control. (E) Single-stranded ( green) but not double-stranded (blue) siRNAs triggered efficient RNAi in wheat germ extracts. The appearance of the $\sim 70$-nucleotide $5^{\prime}$ cleavage product was monitored over time. al. 2001b,c; Nykänen et al. 2001), but triggered only low levels of target cleavage in wheat germ extract (Fig. 1A). We asked if the failure of double-stranded siRNAs to trigger efficient target cleavage in wheat germ extract might reflect a defect in unwinding siRNA duplexes or in assembling the unwound strands into RISC. We monitored siRNA unwinding in wheat germ extract in the presence of ATP; in Drosophila embryo lysate, siRNA unwinding requires ATP (Nykänen et al. 2001). Wheat germ extract, unlike Drosophila embryo lysate, did not unwind doublestranded siRNAs: no single-stranded siRNA accumulated (Fig. 1B) nor did the double-stranded siRNA decrease with time (data not shown). We conclude that wheat germ extract lacks a robust siRNA unwinding activity.

siRNA must contain a $5^{\prime}$ phosphate group to function in RNAi; blocking siRNA 5' phosphorylation inactivates the siRNA (Nykänen et al. 2001; Chiu and Rana 2002; Schwarz et al. 2002). We examined whether the lack of siRNA unwinding in wheat germ extract was caused by the absence of an siRNA kinase. We incubated a $3{ }^{\prime 2} \mathrm{P}$ radiolabeled siRNA bearing a $5^{\prime}$ hydroxyl group in wheat germ extract and monitored its phosphorylation. The siRNA was rapidly phosphorylated in the wheat germ ex- tract, as evidenced by its faster electrophoretic mobility (Fig. 1C). Thus, wheat germ extract contains an siRNA kinase.

If siRNA unwinding, rather than siRNA phosphorylation, is defective in wheat germ extract, then singlestranded, but not double-stranded, siRNAs might direct target mRNA cleavage in the extract. In vitro, in both Drosophila embryo lysates and extracts of cultured mammalian cells, and ex vivo, in cultured mammalian cells, single-stranded siRNAs act as guides for endonucleolytic cleavage, albeit with reduced efficiency (Schwarz et al. 2002). Figures $1 \mathrm{D}$ and $1 \mathrm{E}$ show that single-stranded siRNAs also direct target cleavage in wheat germ extracts. Single-stranded siRNAs functioned in wheat germ extract only when they contained a $5^{\prime}$ phosphate; the siRNAs did not cleave the target when the $5^{\prime}$ end was blocked by a methoxy group (Fig. 1D), consistent with their guiding target cleavage as a component of RISC. A 5 ' methoxy modification blocks RNAi in Drosophila embryo lysates and cultured human cells (Schwarz et al. 2002), because it blocks the assembly of the RLC (Tomari et al. 2004b). Thus, a 5' phosphate is an essential feature of functional siRNAs in both plants and animals. 
In contrast, a 2',3' dideoxy-modified, single-stranded siRNA guided target cleavage in wheat germ extract, excluding a role for the siRNA as a primer of an RNA-dependent RNA polymerase (RdRP) acting to convert the target RNA into dsRNA that is subsequently destroyed by dicing. Over time, only an $\sim 70$-nucleotide product accumulated (Fig. 1E), consistent with the single-stranded siRNA acting directly as a guide without involvement of an RdRP. In Arabidopsis, RdRP proteins are required for PTGS initiated by transgenes overproducing singlestrand RNA (Dalmay et al. 2000; Mourrain et al. 2000), but not for target destruction initiated by dsRNA (Waterhouse et al. 1998).

\section{Biochemical Complementation of Wheat Germ RNAi}

RNA silencing pathways are conserved between plants and animals. Therefore we asked if Drosophila proteins might complement the defect in siRNA unwinding in wheat germ extract. Wheat germ extract was supplemented with serial dilutions of Drosophila embryo lysate and incubated with double-stranded siRNA and an RNA target (Figs. 2A and 2B). After incubation for 60 minutes, we assayed target cleavage (Fig. 2A). Supplementing the wheat germ extract with as little as 1 part Drosophila embryo lysate per 200 activated the wheat germ extract for double-stranded siRNA-directed target cleavage. This amount of Drosophila embryo lysate on its own did not support RNAi, demonstrating that our assay measures biochemical complementation of wheat germ extract by Drosophila proteins. Thus, Drosophila embryo lysate complements wheat germ RNAi activity, even though the two organisms diverged during evolution over one billion years ago (Hedges 2002).

\section{Mutant Drosophila Ovary Lysates Rescue the Wheat Defect}

Because wild-type Drosophila embryo lysate rescued wheat germ, we asked if ovary lysates from Drosophila mutants that are defective in RNAi could rescue wheat germ RNAi (Tomari et al. 2004a,b). Wild-type Drosophila ovary complemented the wheat germ extract for RNAi (Fig. 3A). Lysate from dicer-2, r2d2, and armitage mutant ovaries are all defective in loading RISC with siRNA. We therefore determined if ovary lysate from these mutants can complement wheat germ extract, allowing it to support target cleavage triggered by double-stranded siRNA. We supplemented wheat germ extract with ovary lysate from mutant flies defective for RNAi in vivo and in vitro: $d c r-2^{L 811 f_{s} X}$ and $d c r-2^{G 31 R}$, $r 2 d 2$, and $a r m i^{72.1}$. armi $i^{72.1}$ lysate rescued the wheat germ defect (Fig. 3B), whereas ovary lysate from $r 2 d 2$ (Fig. 3C) and $d c r 2^{L 811 f s X}$ (Fig. 3D) flies did not complement wheat germ RNAi. Dicer-2 and R2D2 are required for siRNA-mediated RNAi (Liu et al. 2003; Lee et al. 2004; Pham et al. 2004), because they are core components of the RLC (Tomari et al. 2004b), which initiates siRNA unwinding (Tomari et al. 2004a). In contrast, $d c r-2^{G 31 R} \mathrm{mu}-$

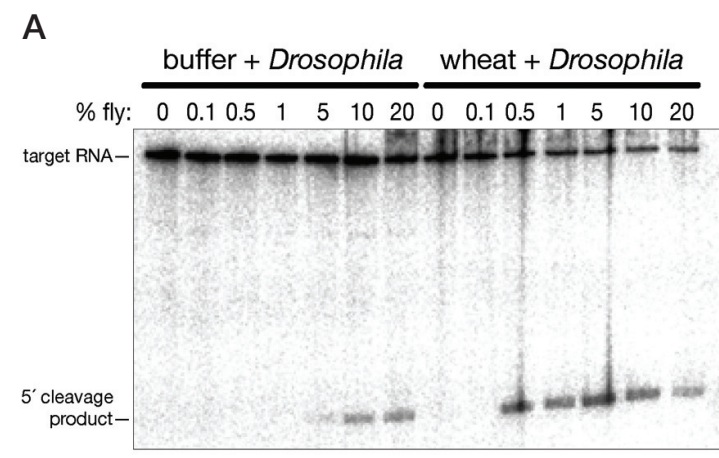

B

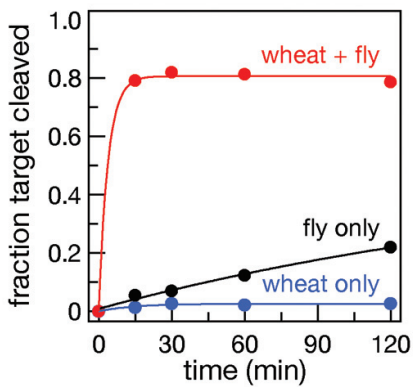

Figure 2. Drosophila RNAi components complement the defect in wheat germ extract, allowing double-stranded siRNA to trigger target cleavage. $(A)$ When wheat germ extract was supplemented with as little as $0.5 \%$ Drosophila embryo lysate, by volume, double-stranded siRNA directed target RNA cleavage. On its own, this amount of Drosophila embryo lysate was insufficient to trigger target cleavage, demonstrating that the Drosophila components complement the defect in wheat germ extract. $(B)$ When the wheat germ was supplemented with Drosophila embryo lysate (red; $5 \%$ of the wheat germ reaction, by volume) nearly all the target RNA was converted to 5 ' cleavage product by $15 \mathrm{~min}$. By contrast, little or no target cleavage was observed for the wheat germ extract alone (blue) at $2 \mathrm{hr}$. At that time, the diluted embryo lysate (black) had converted only $\sim 20 \%$ of the target into $5^{\prime}$ cleavage product.

tant lysate rescued the defect in wheat germ at a concentration insufficient to support RNAi on its own (Fig. 3E). The $d c r-2^{G 31 R}$ mutation prevents Drosophila Dcr-2 protein from dicing long dsRNA into siRNAs, but preserves its function in unwinding siRNA duplexes and loading one of the two siRNA strands into RISC (Lee et al. 2004; Pham et al. 2004; Tomari et al. 2004a). Moreover, recombinant Dicer2/R2D2 heterodimer, which can dice long dsRNA in vitro, did not rescue wheat germ RNAi (Fig. 3F). Together these data suggest that multiple RLC components are missing from wheat germ extract and that these components are essential for the transfer of one of the siRNA strands from the double-stranded siRNA into the single-strand-containing, active RISC.

Next, we tested if Drosophila Argonaute2 (Ago2) is required to complement wheat germ extract. Ago2 is required in flies for siRNA unwinding (Okamura et al. 2004), because the RLC will not initiate siRNA unwinding in the absence of Ago2 (Tomari et al. 2004a). Ago2 is a core component of RISC and is the endonuclease that 
A

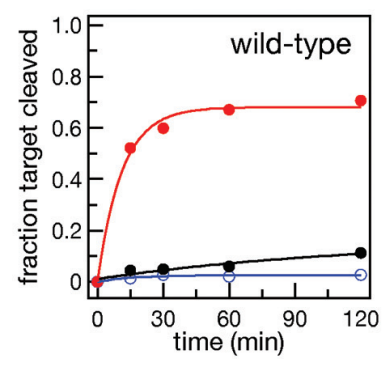

C

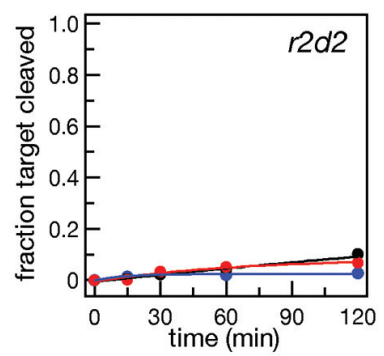

D

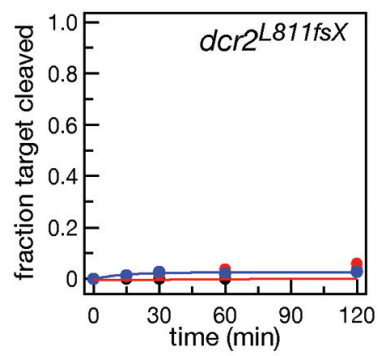

E

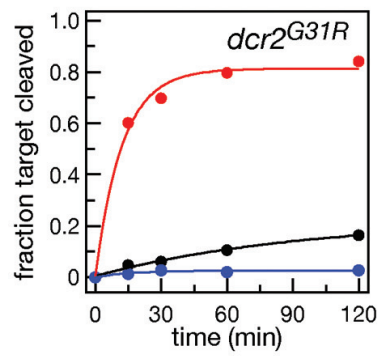

B

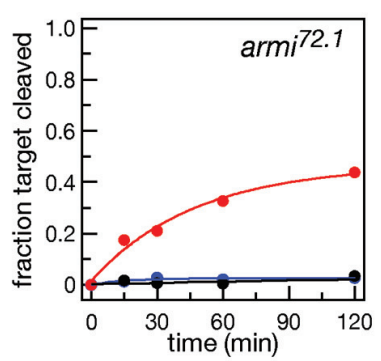

$\mathbf{F}$

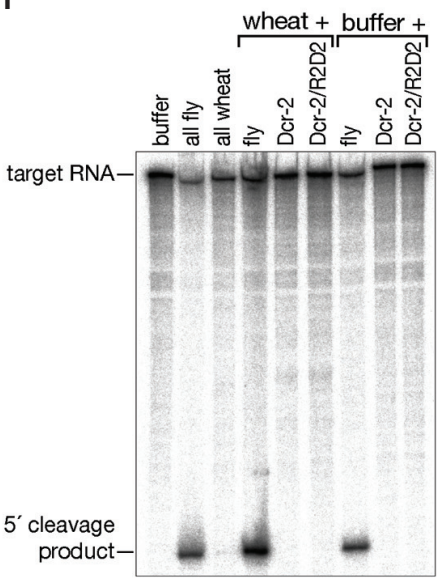

G

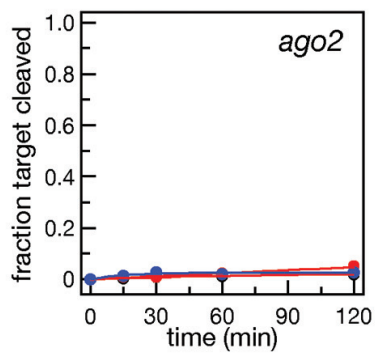

Figure 3. Biochemical complementation of target cleavage (RNAi) directed by doublestranded siRNA in wheat germ extract by Drosophila ovary lysates. Panels $A-E$ and $G$ each show a time course of target RNA cleavage directed by a double-stranded siRNA in wheat germ extract alone (blue), Drosophila ovary lysate alone (black), and wheat germ extract supplemented with Drosophila ovary lysate $(\mathrm{red})$. Wild-type $(A)$ and armitage $\left(\mathrm{armi}^{72.1}\right)(B)$ ovary lysate complemented the wheat germ lysate. In contrast, ovary lysate from $d c r-2^{l 811 f s X}(C)$ or $r 2 d 2(D)$ did not. Ovary lysate from the $d c r-2^{G 3 I R}$ allele $(E)$, which is defective for dicing long dsRNA into siRNAs, but not for unwinding siRNA duplexes, complemented wheat germ extract. $(F)$ Recombinant Dcr-2 protein or recombinant Dcr-2/R2D2 heterodimer were not sufficient to rescue wheat germ, when used at a physiologically relevant concentration. $(G)$ Ovary lysates from flies mutant for ago 2 did not rescue the RNAi in the wheat germ extract. "slices" the target RNA (Liu et al. 2004; Meister et al. 2004; Parker et al. 2004; Song et al. 2004). However, it is not known if the endonuclease activity of Ago2 is required for its role in RISC assembly. We prepared ovary lysates from ago $2^{16608}$ flies, a strong ago 2 allele. Intriguingly, ago $2^{16608}$ lysates, unlike those from armi $i^{72.1} \mathrm{mu}-$ tant flies, did not rescue the wheat germ RNAi defect (Fig. 3G), suggesting that wheat germ extract requires the function of the RLC and that the wheat germ extract lacks the RISC assembly machinery.

\section{Conclusions}

Here, we show that single-stranded siRNAs direct target RNA cleavage in wheat germ extracts. Like RNAi in animals, a 5' phosphate is required for this siRNA function. Reconstitution of immunopurified human Argonaute 2 similarly requires a $5^{\prime}$ phosphate (Liu et al. 2004), and structural and kinetic studies argue that Argonaute proteins in general contain a pocket that binds the siRNA 5' end, perhaps via phosphate interactions (Haley and Zamore 2004; Parker et al. 2004). Our data are consistent with this phosphate-binding pocket also being conserved in plant Argonaute proteins.

Although single-stranded siRNAs can trigger RNAi in wheat germ extract, these extracts cannot be programmed with double-stranded siRNA. Our data suggest that siRNA duplexes do not enter the RNAi pathway in wheat germ extract because they are not unwound. Biochemical complementation experiments with wild-type and mutant Drosophila ovary lysates show that wheat germ extract lacks multiple components of the RISC-loading machinery. We do not know if this reflects the absence of these components from the extract or if they are not present in 
intact wheat embryos. In contrast, wheat embryos clearly contain miRNA-programmed RISCs, since many functional miRNAs are present in wheat germ extract (G. Tang and P.D. Zamore, unpubl.). Wheat embryos may contain a functional RISC-assembly machinery dedicated strictly to the production of miRNA-containing RISC, but may lack the comparable assembly machinery for siRNAs. Alternatively, RISC may be loaded with miRNAs during wheat germ cell development, and mature wheat embryos may lack some or all RISC-assembly components.

Ovary lysates lacking the Drosophila protein armitage, which is required for RISC assembly and RNAi in vitro and in vivo (Cook et al. 2004; Tomari et al. 2004b) complement wheat germ extracts for RNAi triggered by siRNA duplexes. The Armitage protein is the animal homolog of the plant protein SDE3, which may be present in plant cell extracts. In contrast, ago $2^{16608}, r 2 d 2$, and dicer $2^{L 811 f_{s} X \text { mutant }}$ lysates, all of which are defective in siRNA unwinding and RISC assembly, do not complement wheat germ extract. Thus, at least three different Drosophila RISC assembly proteins are required to rescue the defect in wheat germ extract.

\section{MATERIALS AND METHODS}

\section{General Methods}

Wheat germ extract preparation (Tang et al. 2003), target cleavage assays (Haley et al. 2003), RNAi triggered with single-stranded siRNAs (Schwarz et al. 2002), siRNA phosphorylation and unwinding assays (Nykänen et al. 2001), and Drosophila ovary lysate preparation (Tomari et al. 2004b) were as described previously.

\section{SiRNAs}

siRNAs were prepared by standard synthesis (Dharmacon Research). Antisense siRNAs targeting firefly luciferase mRNA were $5^{\prime}$-HO-UCG AAG UAU UCC GCG UAC GUG-3'(5' OH, riboU); 5'-CH ${ }_{3} \mathrm{O}-\mathrm{dTCG}$ AAG UAU UCC GCG UAC GUG-3' (5' $\mathrm{CH}_{3} \mathrm{O}$, dT); 5' HO-UCG AAG UAU UCC GCG UAC GUddC (2',3'dideoxyC). let-7 siRNAs contained a guide strand with the sequence $5^{\prime}$-HO-UGA GGU AGU AGG UUG UAU AGU-3'. Sense strands used were 5'-HO-CGU ACG CGG AAU ACU UCG AAA-3' for $P p$-luc and 5'HO-GCU ACA ACC UAC UAC CUC CUU-3' for the let-7 siRNA. Sense and antisense strands were annealed as described (Elbashir et al. 2001c). siRNAs were labeled using polynucleotide kinase (New England Biolabs) and $\gamma-{ }^{32} \mathrm{P}-\mathrm{ATP}(\mathrm{NEN})$ or poly(A) polymerase (Life Technologies) and $\alpha-{ }^{32} \mathrm{P}$-cordycepin-5' - triphosphate (NEN) as described (Haley et al. 2003).

\section{ACKNOWLEDGMENTS}

We thank Guiliang Tang, Tingting Du, and Yukihide Tomari for help preparing wheat germ extract, ovary lysate, and recombinant proteins; members of the Zamore laboratory for advice and support; and Qinghua Liu, Dean Smith, Richard Carthew, Erik Sontheimer, and
Makiko and Haruhiko Siomi for Drosophila stocks. P.D.Z. is a W.M. Keck Foundation Young Scholar in Medical Research. Supported in part by grants from the National Institutes of Health to P.D.Z. (GM62862-01 and GM65236-01).

\section{REFERENCES}

Bernstein E., Caudy A.A., Hammond S.M., and Hannon G.J. 2001. Role for a bidentate ribonuclease in the initiation step of RNA interference. Nature 409: 363.

Billy E., Brondani V., Zhang H., Muller U., and Filipowicz W. 2001. Specific interference with gene expression induced by long, double-stranded RNA in mouse embryonal teratocarcinoma cell lines. Proc. Natl. Acad. Sci. 98: 14428.

Boutla A., Delidakis C., Livadaras I., Tsagris M., and Tabler M. 2001. Short 5'-phosphorylated double-stranded RNAs induce RNA interference in Drosophila. Curr. Biol. 11: 1776.

Caplen N.J., Parrish S., Imani F., Fire A., and Morgan R.A. 2001. Specific inhibition of gene expression by small doublestranded RNAs in invertebrate and vertebrate systems. Proc. Natl. Acad. Sci. 98: 9742.

Catalanotto C., Azzalin G., Macino G., and Cogoni C. 2002. Involvement of small RNAs and role of the qde genes in the gene silencing pathway in Neurospora. Genes Dev. 16: 790

Caudy A.A., Myers M., Hannon G.J., and Hammond S.M. 2002. Fragile X-related protein and VIG associate with the RNA interference machinery. Genes Dev. 16: 2491

Chiu Y.-L. and Rana T.M. 2002. RNAi in human cells: Basic structural and functional features of small interfering RNA. Mol. Cell 10: 549.

Cogoni C., Irelan J.T., Schumacher M., Schmidhauser T.J., Selker E.U., and Macino G. 1996. Transgene silencing of the al-1 gene in vegetative cells of Neurospora is mediated by a cytoplasmic effector and does not depend on DNA-DNA interactions or DNA methylation. EMBO J. 15: 3153.

Cook H.A., Koppetsch B.S., Wu J., and Theurkauf W.E. 2004. The Drosophila SDE3 homolog armitage is required for oskar mRNA silencing and embryonic axis specification. Cell 116: 817.

Dalmay T., Horsefield R., Braunstein T.H., and Baulcombe D.C. 2001. SDE3 encodes an RNA helicase required for post-transcriptional gene silencing in Arabidopsis. EMBO J. 20: 2069.

Dalmay T., Hamilton A., Rudd S., Angell S., and Baulcombe D.C. 2000. An RNA-dependent RNA polymerase gene in Arabidopsis is required for posttranscriptional gene silencing mediated by a transgene but not by a virus. Cell 101: 543 .

Doi N., Zenno S., Ueda R., Ohki-Hamazaki H., Ui-Tei K., and Saigo K. 2003. Short-interfering-RNA-mediated gene silencing in mammalian cells requires Dicer and eIF2C translation initiation factors. Curr. Biol. 13: 41.

Elbashir S.M., Lendeckel W., and Tuschl T. 2001a. RNA interference is mediated by 21- and 22-nucleotide RNAs. Genes Dev. 15: 188

Elbashir S.M., Martinez J., Patkaniowska A., Lendeckel W., and Tuschl T. 2001b. Functional anatomy of siRNAs for mediating efficient RNAi in Drosophila melanogaster embryo lysate. $E M B O J .20: 6877$.

Elbashir S.M., Harborth J., Lendeckel W., Yalcin A., Weber K., and Tuschl T. 2001c. Duplexes of 21-nucleotide RNAs mediate RNA interference in cultured mammalian cells. Nature 411: 494.

Fagard M., Boutet S., Morel J.-B., Bellini C., and Vaucheret H. 2000. AGO1, QDE-2, and RDE-1 are related proteins required for post-transcriptional gene silencing in plants, quelling in fungi, and RNA interference in animals. Proc. Natl. Acad. Sci. 97: 11650.

Fire A., Xu S., Montgomery M.K., Kostas S.A., Driver S.E., and Mello C.C. 1998. Potent and specific genetic interference by double-stranded RNA in Caenorhabditis elegans. Nature 391: 806.

Grishok A., Tabara H., and Mello C. 2000. Genetic requirements for inheritance of RNAi in C. elegans. Science 287: 2494. 
Haley B. and Zamore P.D. 2004. Kinetic analysis of the RNAi enzyme complex. Nat. Struct. Mol. Biol. 11: 599.

Haley B., Tang G., and Zamore P.D. 2003. In vitro analysis of RNA interference in Drosophila melanogaster. Methods 30: 330.

Hamilton A.J. and Baulcombe D.C. 1999. A species of small antisense RNA in posttranscriptional gene silencing in plants. Science 286: 950.

Hammond S.M., Bernstein E., Beach D., and Hannon G.J. 2000. An RNA-directed nuclease mediates post-transcriptional gene silencing in Drosophila cells. Nature 404: 293.

Hammond S.M., Boettcher S., Caudy A.A., Kobayashi R., and Hannon G.J. 2001. Argonaute2, a link between genetic and biochemical analyses of RNAi. Science 293: 1146.

Hedges S.B. 2002. The origin and evolution of model organisms. Nat. Rev. Genet. 3: 838 .

Hutvágner G. and Zamore P.D. 2002. A microRNA in a multiple-turnover RNAi enzyme complex. Science 297: 2056.

Hutvágner G., Simard M.J., Mello C.C., and Zamore P.D. 2004. Sequence-specific inhibition of small RNA function. PLoS Biol. 2: 465.

Kennerdell J.R. and Carthew R.W. 1998. Use of dsRNA-mediated genetic interference to demonstrate that frizzled and frizzled 2 act in the wingless pathway. Cell 95: 1017.

Lee Y.S., Nakahara K., Pham J.W., Kim K., He Z., Sontheimer E.J., and Carthew R.W. 2004. Distinct roles for Drosophila Dicer-1 and Dicer-2 in the siRNA/miRNA silencing pathways. Cell 117: 69.

Liu J., Carmell M.A., Rivas F.V., Marsden C.G., Thomson J.M., Song J.J., Hammond S.M., Joshua-Tor L., and Hannon G.J. 2004. Argonaute 2 is the catalytic engine of mammalian RNAi. Science 305: 1437.

Liu Q., Rand T.A., Kalidas S., Du F., Kim H.E., Smith D.P., and Wang X. 2003. R2D2, a bridge between the initiation and effector steps of the Drosophila RNAi pathway. Science 301: 1921.

Lohmann J.U., Endl I., and Bosch T.C. 1999. Silencing of developmental genes in Hydra. Dev. Biol. 214: 211.

Mallory A., Reinhart B., Jones-Rhoades M., Tang G., Zamore P., Barton M., and Bartel D. 2004. MicroRNA control of PHABULOSA in leaf development: Importance of pairing to the microRNA 5' region. $E M B O J .23: 3356$.

Martinez J. and Tuschl T. 2004. RISC is a 5' phosphomonoesterproducing RNA endonuclease. Genes Dev. 18: 975.

Martinez J., Patkaniowska A., Urlaub H., Lührmann R., and Tuschl T. 2002. Single-stranded antisense siRNA guide target RNA cleavage in RNAi. Cell 110: 563.

Meister G., Landthaler M., Patkaniowska A., Dorsett Y., Teng G., and Tuschl T. 2004. Human Argonaute2 mediates RNA cleavage targeted by miRNAs and siRNAs. Mol. Cell 15: 185 .

Morel J.B., Godon C., Mourrain P., Beclin C., Boutet S., Feuerbach F., Proux F., and Vaucheret H. 2002. Fertile hypomorphic ARGONAUTE (ago1) mutants impaired in post-transcriptional gene silencing and virus resistance. Plant Cell 14: 629.

Mourelatos Z., Dostie J., Paushkin S., Sharma A.K., Charroux B., Abel L., Rappsilber J., Mann M., and Dreyfuss G. 2002. miRNPs: A novel class of ribonucleoproteins containing numerous microRNAs. Genes Dev. 16: 720.

Mourrain P., Beclin C., Elmayan T., Feuerbach F., Godon C., Morel J.B., Jouette D., Lacombe A.M., Nikic S., Picault N., Remoue K., Sanial M., Vo T.A., and Vaucheret H. 2000. Arabidopsis SGS2 and SGS3 genes are required for posttranscriptional gene silencing and natural virus resistance. Cell 101: 533.

Ngo H., Tschudi C., Gull K., and Ullu E. 1998. Double-stranded RNA induces mRNA degradation in Trypanosoma brucei. Proc. Natl. Acad. Sci. 95: 14687.

Nykänen A., Haley B., and Zamore P.D. 2001. ATP requirements and small interfering RNA structure in the RNA interference pathway. Cell 107: 309.

Okamura K., Ishizuka A., Siomi H., and Siomi M.C. 2004. Distinct roles for Argonaute proteins in small RNA-directed RNA cleavage pathways. Genes Dev. 18: 1655.

Pal-Bhadra M., Bhadra U., and Birchler J.A. 2002. RNAi related mechanisms affect both transcriptional and posttranscriptional transgene silencing in Drosophila. Mol. Cell 9: 315.

Parker J.S., Roe S.M., and Barford D. 2004. Crystal structure of a PIWI protein suggests mechanisms for siRNA recognition and slicer activity. EMBO J. 23: 4727.

Pham J.W., Pellino J.L., Lee Y.S., Carthew R.W., and Sontheimer E.J. 2004. A Dicer-2-dependent 80s complex cleaves targeted mRNAs during RNAi in Drosophila. Cell 117: 83.

Rand T.A., Ginalski K., Grishin N.V., and Wang X. 2004. Biochemical identification of Argonaute 2 as the sole protein required for RNA-induced silencing complex activity. Proc. Natl. Acad. Sci. 101: 14385.

Sánchez-Alvarado A. and Newmark P.A. 1999. Double-stranded RNA specifically disrupts gene expression during planarian regeneration. Proc. Natl. Acad. Sci. 96: 5049.

Schramke V. and Allshire R. 2003. Hairpin RNAs and retrotransposon LTRs effect RNAi and chromatin-based gene silencing. Science 301: 1069.

Schwarz D.S., Hutvágner G., Haley B., and Zamore P.D. 2002. Evidence that siRNAs function as guides, not primers, in the Drosophila and human RNAi pathways. Mol. Cell 10: 537.

Song J.J., Smith S.K., Hannon G.J., and Joshua-Tor L. 2004. Crystal structure of Argonaute and its implications for RISC slicer activity. Science 305: 1434.

Tabara H., Yigit E., Siomi H., and Mello C.C. 2002. The dsRNA binding protein RDE-4 interacts with RDE-1, DCR-1, and a DexH-box helicase to direct RNAi in C. elegans. Cell 109: 861.

Tabara H., Sarkissian M., Kelly W.G., Fleenor J., Grishok A., Timmons L., Fire A., and Mello C.C. 1999. The rde-1 gene, RNA interference, and transposon silencing in C. elegans. Cell 99: 123 .

Tang G., Reinhart B.J., Bartel D.P., and Zamore P.D. 2003. A biochemical framework for RNA silencing in plants. Genes Dev. 17: 49

Timmons L. and Fire A. 1998. Specific interference by ingested dsRNA. Nature 395: 854.

Tomari Y., Matranga C., Haley B., Martinez N., and Zamore P.D. 2004a. A protein sensor for siRNA asymmetry. Science 306: 1377.

Tomari Y., Du T., Haley B., Schwarz D.S., Bennett R., Cook H.A., Koppetsch B.S., Theurkauf W.E., and Zamore P.D. 2004b. RISC assembly defects in the Drosophila RNAi mutant armitage. Cell 116: 831.

Vaucheret H., Beclin C., Elmayan T., Feuerbach F., Godon C., Morel J.B., Mourrain P., Palauqui J.C., and Vernhettes S. 1998. Transgene-induced gene silencing in plants. Plant J. 16: 651.

Volpe T.A., Kidner C., Hall I.M., Teng G., Grewal S.I.S., and Martienssen R.A. 2002. Regulation of heterochromatic silencing and histone H3 lysine-9 methylation by RNAi. Science 297: 1833.

Waterhouse P.M., Graham M.W., and Wang M.B. 1998. Virus resistance and gene silencing in plants can be induced by simultaneous expression of sense and antisense RNA. Proc. Natl. Acad. Sci. 95: 13959.

Wianny F. and Zernicka-Goetz M. 2000. Specific interference with gene function by double-stranded RNA in early mouse development. Nat. Cell Biol. 2: 70.

Williams R.W. and Rubin G.M. 2002. ARGONAUTE1 is required for efficient RNA interference in Drosophila embryos. Proc. Natl. Acad. Sci. 99: 6889.

Zamore P.D., Tuschl T., Sharp P.A., and Bartel D.P. 2000. RNAi: Double-stranded RNA directs the ATP-dependent cleavage of mRNA at 21 to 23 nucleotide intervals. Cell 101: 25 . 


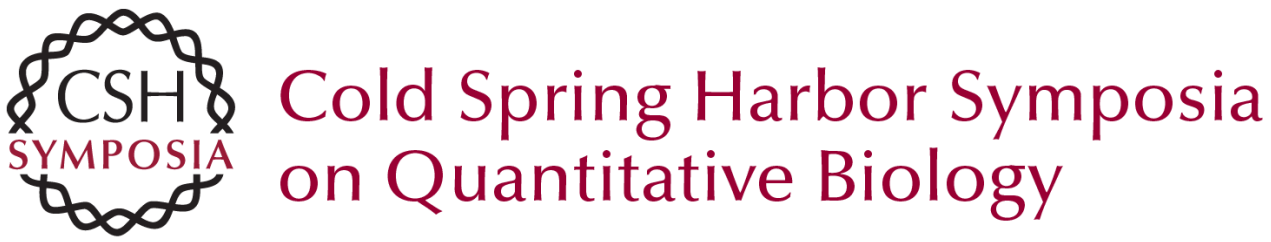

\section{Plant RNA Interference in Vitro}

C. MATRANGA and P.D. ZAMORE

Cold Spring Harb Symp Quant Biol 2004 69: 403-408

Access the most recent version at doi:10.1101/sqb.2004.69.403

References This article cites 61 articles, 30 of which can be accessed free at: http://symposium.cshlp.org/content/69/403.full.html\#ref-list-1

\section{License}

Email Alerting Receive free email alerts when new articles cite this article - sign up in Service the box at the top right corner of the article or click here. 